\title{
Karya Tari Dangiang Wulung sebagai Identitas Kecamatan Selaawi Kabupaten Garut
}

\author{
Komarudin, Meiga Fristya Laras Sakti \\ Institut Seni Budaya Indonesia Bandung \\ Jalan Buah Batu no 212 Bandung \\ Tlp.08122436350,E-mail: margaya212@gmail.com
}

\begin{abstract}
Selaawi District is one of the areas in Garut Regency. Selaawi is known for its many craftsmen who make handicrafts from bamboo. Several types of art that exist in Selaawi use bamboo as the material for making it. Of the various forms of art that exist, but there is no cultivation of dance that uses bamboo. Therefore, the cultivation of the dance work "Dangiang Wulung" uses bamboo elements both from the property and the dance costumes. The method used in the creation of this dance uses the participation action research (PAR) method. The method used to obtain the work of this research is divided into two stages, namely: exploratory experimental method and development experiment method. In the formation of this dance work using experimental techniques in which it is formed from exploration, improvisation and formation. The results of the process of forming the Dangiang Wulung dance show that the use of bamboo in this dance produces a traditional dance work that elevates the Selaawi cultural locus as the cultural identity.
\end{abstract}

Keywords: Dangiang Wulung dance, identity, creative, Selaawi.

\begin{abstract}
ABSTRAK
Kecamatan Selaawi merupakan salah satu daerah di Kabupaten Garut. Selaawi dikenal dengan banyaknya pengrajin yang membuat kerajinan tangan dari bambu. Beberapa jenis kesenian yang ada di Selaawi ini banyak memanfaatkan bambu sebagai bahan pembuatannya. Dari berbagai bentuk kesenian di Selaawi, belum ada penggarapan tari yang menggunakan bambu sebagai bahan penggarapannya. Maka dari itu, penggarapan karya tari Dangiang Wulung ini menggunakan unsur bambu baik dari alat musik, properti, dan kostum tarinya. Penggunaan metode dalam penciptaan tari ini menggunakan metode Participation Action Reseach (PAR). Metode yang dilakukan untuk memperoleh hasil karya dari penelitian ini dibagi dalam dua tahapan yaitu: metode eksperimen eksploratif dan metode eksperimen pengembangan. Dalam pembetukan karya tari ini menggunakan teknik eksperimen yang di dalamnya terbentuk dari eksplorasi, improvisasi, dan pembentukan. Hasil dari proses pembentukan tari Dangiang Wulung ini menunjukkan bahwa penggunaan bambu pada tarian ini, menghasilkan sebuah karya tari tradisi yang mengangkat locus budaya Selaawi sebagai identitas budayanya.
\end{abstract}

Kata kunci: Tari Dangiang Wulung, identitas, kreativitas, dan Selaawi.

\section{PENDAHULUAN}

Kecamatan Selaawi merupakan salah satu kecamatan yang berada di wilayah Kabupaten Garut. Habit masyarakat di Kecamatan Selaawi ini begitu agamis karena lingkungan pesantren yang sangat lekat dengan kehidupan masyarakatnya. Meskipun demikian, kesenian di daerah ini tumbuh dan berkembang. Hal ini terlihat dengan adanya beberapa kesenian yang masih dilestarikan 
seperti Cigawiran, Marawis, Terbang, Gondang, Pencak Silat Bambu Runcing, Pecel (Pencak Silat Celentung), dan Celentung. Selain itu juga, Selaawi dikenal dengan banyaknya pengrajin yang membuat kerajinan tangan dari bambu. Kerajinan tersebut ada yang berupa kebutuhan alat rumah tangga seperti hihid, boboko, nyiru, pepetek, bongsang, dan lain sebagainya. Pemanfaatan bambu itu juga dibuat oleh masyarakat menjadi sebuah ide kreatif dalam berkesenian.

Pemanfaatan bambu oleh masyarakat Selaawi memiliki peran yang sangat besar. Pohon jenis bambu bersifat lentur dan ringan, selain itu juga tidak mudah patah dan memiliki serat yang rapat. Seperti yang dijelaskan bahwa,

"Dalam kehidupan masyarakat pedesaan di Indonesia, bambu memegang peranan sangat penting. Bahan bambu dikenal oleh masyarakat memiliki sifatsifat yang baik untuk dimanfaatkan, antara lain batangnya kuat, ulet, lurus, rata, keras, mudah dibelah, mudah dibentuk dan mudah dikerjakan serta ringan sehingga mudah diangkut". (Widnyana, 2021, hlm. 2).

Sifat bambu tersebut jika diolah menjadi alat musik ataupun bahan pembuatan properti kostum tari tentu akan sangat bermanfaat. Pemanfaatannya dalam hal perkembangan seni dan budaya di daerah Selaawi masih sangat kurang terutama untuk bidang musik/ karawitan dan seni tari. Maka dari itu, penulis mencoba mengembangkan seni dan budaya di Kecamatan Selaawi ini dengan mengolah media bambu sebagai pemanfaatan sumber daya alamnya. Azas atau konsep tersebut, "pada dasarnya dapat diterapkan kepada semua jenis kesenian etnik-tradisional yang menghadapi masalah kemerosotan dan bahkan kemusnahan". (Saini KM, 2008, hlm. 240)

Pada beberapa kesenian yang ada, belum adanya penggarapan tarian yang berhubungan dengan kekhasan daerah tersebut dengan penggunaan bambu sebagai ciri khasnya. Oleh karena itu, untuk dapat melestarikan potensi budaya yang dimiliki oleh Kabupaten Garut khususnya di Kecamatan Selaawi, maka karya tari Dangiang Wulung ini dengan menggabungkan unsur musik, properti, dan kostum dari media bambu mampu diharapkan mampu menampilkan ciri khas daerahnya. Istilah Dangiang merupakan wibawa, sedangkan Wulung merupakan jenis bambu, maka Dangiang Wulung ini berarti memberikan nilai tambah pencitraan dalam kewibawaan bambu. Tari kreasi ini dibuat berdasarkan potensi budaya yang dimiliki oleh Kecamataan Selaawi. Dari hasil penelitian ini diharapkan menambah vokabuler material seni bagi Kecamatan Selaawi, khususnya memiliki tarian yang menjadikan penguatan ikon Selaawi.

Berangkat dari pemaparan di atas, tentunya terdapat tujuan dan manfaat yang bersifat teoritis dan praktis. Pada tujuan dan manfaat teoritis, penelitian ini mencoba untuk mengungkapkan pengetahuan baru mengenai alternatif pengembangan media bambu dalam bentuk tari kreasi. Tujuan dan manfaat praktisnya, penelitian ini dapat mewujudkan sebuah karya tari kreasi baru yang bisa digunakan sebagai identitas baru bagi masyarakat Kecamatan Selaawi.

Pada penelitian karya ini yang menjadi 
kekhawatiran akan kurangnya potensi seni budaya pada bidang tari di Kecamatan Selaawi ini adalah masih kurangnya bentuk kesenian khususnya pada bidang tari. Kurangnya bentuk kesenian di Kecamatan Selaawi ini karena tidak terjamah oleh seniman daerah. Terlebih lagi, Kecamatan Selaawi yang telah menjadi desa wisata dan membuat gedung kesenian yang nantinya karya tari ini dimanfaatkan juga sebagai upaya daya tarik para wisatawan untuk berkunjung.

Upaya untuk melakukan penciptaan tari kreasi ini berdasarkan pada rencana pemerintah untuk membuat desa wisata di Kecamatan Selaawi pada tahun 2021. Desa wisata ini, bertujuan untuk mengangkat potensi lokal berupa pengembangan bambu baik di bidang hand craft maupun seni. Pemerintah setempat sangat antusias ingin mengembangkan potensi seni yang berbasis bambu tersebut. Hal ini serupa dengan pendapat Brandon yang menegaskan bahwa, "dukungan sosial adalah adanya kontrak sosial yang mengatur hubungan antara sebuah grup dan pendukung-pendukungnya yaitu: dukungan pemerintah, dukungan komersial, dan dukungan komunal". (Brandon, 2003, hlm. 188-189)

Pada karya tari Dangiang Wulung ini menampilkan sebuah karya baru atau yang popular di kalangan masyarakat Selaawi. Hal tersebut dimaksudkan agar upaya pelestariannya tetap berjalan dan digemari oleh masyarakat sekitar. Seperti pendapat Soedarsono bahwa, "seni pertunjukan profan yang profesional atau komersial nasibnya 'memprihatinkan', kecuali beberapa pertunjukan pop yang mampu meraih massa penonton" (Soedarsono, 1997, hlm.81).Dengan demikian dimaksudkan agar tarian tersebut dapat tumbuh dan berkembang di lingkungan masyarakat Selaawi bahkan menjadi identitas kesenian baru di lingkungannya.

Dalam hal ini Arthur S. Nalan menyebutnya dengan istilah Progress Revitalization yang merupakan gerakan baru untuk memberi interpretasi baru, makna baru, impresi baru, dari proses menghidupkan kembali dengan aura baru yang sejalan dengan zaman. (Nalan, 2008, hlm. 90) Artinya transformasi atau Progress Revitalization memuat pengembangan estetik untuk membekali para penyangga seni tradisi.

Pembentukan karya Tari Dangiang Wulung ini pun diambil berdasarkan pola kehidupan budaya masyarakat Selaawi. Pola budaya masyarakat sejatinya akan terus berjalan, dengan demikian kehidupan kesenian yang bersumber dari budaya akan tumbuh dan memiliki identitas bagi masyarakatnya. Seperti dikatakan Stuart Hall, bahwa identitas adalah produk yang terus berjalan dari sejarah dan budaya, dan bukan merupakan produk yang sudah selesai. (Wikipedia, 2021) Maka dari itu, pembuatan Karya tari Dangiang Wulung yang bersumber pada potensi bambu ini, dikemas menjadi sebuah tarian kreasi yang popular sesuai dengan perkembangan jaman, tetapi tidak menghilangkan unsur budaya dan gaya yang ada di lingkungan Selaawi. Selain itu juga, karya ini bersumber dari pola budaya masyarakat agar menciptakan sebuah identitas maupun gaya bagi masyarakat Kecamatan Selaawi. Dengan menciptakan tarian ini tentunya akan menghasilkan pula bentuk dan gaya, menurut Wahyuni mengatakan, bahwa 
Persoalan gaya tari menjadi penting karena dengan mengenali gaya-gaya tari, kita bisa membedakan gaya-gaya seni tari tradisional kerakyatan (folk dances) yang berbeda dengan konteks kultural yang berbeda. (2018, hlm. 246).

\section{METODE}

Pengertian metode dapat diartikan sebagai cara, proses, dan langkah-langkah yang dilakukan oleh peneliti untuk dapat melakukan penelitian untuk memperoleh capaian atau tujuan tertentu. Kaitannya dengan pengertian metode penelitian, Royce mengatakan lebih detail yaitu menarik simpulan, menyajikan teori, membandingkan tarian dari kebudayaan lain baik yang dekat atau jauh, dalam kejelasan sejarah. (Royce, 1976, hlm. 41) Merespon pendapat tersebut, untuk dapat mengungkap penelitian karya ini, maka digunakan penelitian kualitatif dengan metode participation action reseach (PAR).

Metode PAR terdiri atas tiga kata yang membentuk daur (siklus) dan saling berkaitan satu dengan yang lainnya yakni partisipasi, riset, dan aksi. (Norman K. Denzin, 2009, hlm. 424-428). Partisipasi merupakan bentuk kepedulian terhadap keberadaan kondisi masyarakatSelaawiyangsangatmembutuhkan campur tangan dari pihak akademisi dalam membangun dan mengembangkan potensi lokal genius. Bentuk kepedulian tersebut ditindaklanjuti dengan riset yang mengarah pada suatu tujuan untuk membuat karya tari sebagai ciri identitas daerah. Melakukan riset berarti membangun aksi untuk berpartisipasi dalam merespon bambu menjadi penciptaan tari kreasi. Penciptaan tari kreasi ini tidak

\section{Diagram 1. Alur Penelitian Karya Tari Dangiang Wulung}

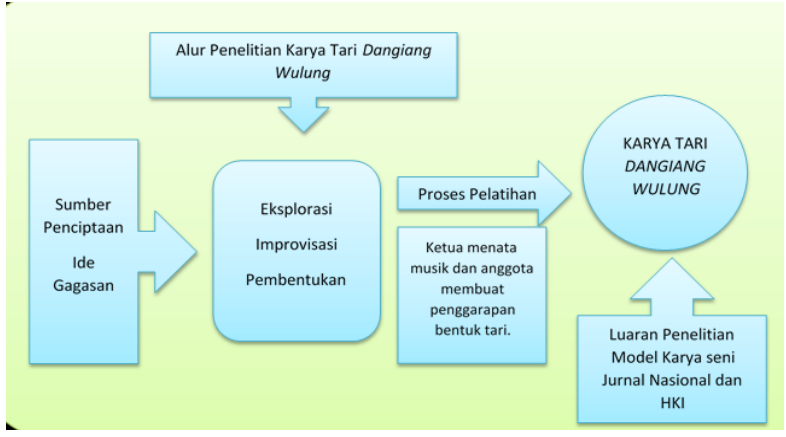

hanya dalam bentuk Garapan gerak tari dan musiknya saja, tetapi juga pada alat musik yang digunakan untuk mengiringi tarinya.

Metode yang dilakukan untuk memperoleh hasil karya dari penelitian ini dibagi dalam dua tahapan yaitu: metode eksperimen eksploratif dan metode eksperimen pengembangan.

1. Eksperimen eksploratif, adalah pencarian gerak berdasarkan pada gerak keseharian. Penjelajahan gerak juga didapatkan dari unsur-unsur kesenian yang ada di Selaawi agar tidak menghilangkan unsur kebudayaannya. Selain itu pada eksploratif ini dilakukan untuk membuat kerangka dan desain untuk alat musik yang digunakan.

2. Eksperimen pengembangan, adalah proses kreatif berupa kegiatan mengembangkan gerak-gerak yang sudah didapatkan pada proseseksplorasi untuk disusun menjadi gerak tarian baru yang dipadukan dengan iringan musik. Sedangkan untuk alat musik dan iringan dilakukan pengembangan dalam bentuk alat musik dan bentuk irama dari iringan tarinya.

Berdasarkan diagram 1, untuk membuat karya seni Tari Dangiang Wulung ini 
dibagi menjadi tiga tahap yaitu eksplorasi, improvisasi dan pembentukan. Pada setiap tahapan tersebut peneliti menerapkannya pada proses pembuatan gerak tari, proses pembuatan alat musik dan proses pembuatan iringan tarinya. Tahap tersebut dijelaskan sebagai berikut:

\section{Tahap Ekplorasi}

Pada tahap eksplorasi ini penulis menggunakan pengalaman dan pengetahuan untuk dapat mengeksplorasi gerak secara kasar. Selain itu, menjajaki beberapa sumber untuk bahan pertimbangan. Secara eksplisit tahap ekplorasi dalam proses penciptaan seni dijelaskan (Sumandiyo Hadi, 2003, hlm. 65) bahwa "secara umum dapat diartikan sebagai suatu proses penjajagan, yaitu sebagai pengalaman untuk menanggapi obyek dari luar, atau aktivitasnya mendapat rangsang dari luar. Eksplorasi meliputi berpikir, berimajinasi, merasakan, dan merespon". Hal tersebut juga berlaku pada proses penciptaan karya seni ini, seperti halnya pada eksplorasi gerak dengan melihat dari gerak keseharian, gerak popularitas dari kesenian yang ada, gerak pencak silat, dan eksplorasi pemanfaatan kerajinan bambu menjadi properti tari. Pada bentuk alat musik tahap eksplorasi ini juga dilakukan pembuatan alat yang berbentuk kohkol yang biasa dipakai masyarakat, berbentuk gamelan seperti saron, selentem dan lainnya. Sedangkan bentuk eksplorasi musik iringan yang digunakan untuk mengiringi tarian ini lebih kepada pengatur suasana dan juga memberikan kesan identitas Selaawi dengan memberikan sentuhan Cigawiran yang merupakan salah satu kesenian di Selaawi.

\section{Improvisasi}

Tahap improvisasi berupa kegiatan mengembangkan gerak-gerak yang sudah dibakukan untuk disusun menjadi gerak tarian baru yang dipadukan dengan iringan musik. Pada proses ini, pengalaman tari merupakan bekal yang sangat diperlukan khususnya pada proses pembentukan koreografi. Melalui improvisasi diharapkan para penari mempunyai keterbukaan yang bebas untuk mengekspresikan perasaannya lewat media gerak. Sumandiyo Hadi menjelaskan bahwa "improvisasi diartikan sebagai penemuan gerak secara kebetulan atau spontan, walaupun gerak-gerak tertentu muncul dari gerak-gerak yang pernah dipelajari atau ditemukan sebelumnya, tetapi ciri spontanitas menandai hadirnya improvisasi". (Sumandiyo Hadi, 2003, hlm. 70). Selanjutnya dijelaskan oleh Hawkins bahwa "kreativitas melalui improvisasi sering diartikan sebagai terbang ke yang tak diketahui". (Alma M. Hawkins, 1991, hlm. 19). Oleh karena itu proses improvisasi yang dilakukan pada penciptaan tariani ini yang meliputi gerak, alat musik, iringan tari, dan properti tari ini, banyak mengolah bentuk yang ada disekitar masyarakat. Salah satu contohnya dalam mengolah gerak improvisasi pada saat melakukan latihan gabungan dengan musik gerak improvisasi muncul pada saat mendengar musik.

\section{Pembentukan}

Pada pembentukan ini, mencoba untuk menata koreografi, iringan musik dan properti pada tariannya sehingga menjadi satu kesatuan yang utuh. Proses pembentukan ini diperoleh dari pengejawantahan eksplorasi dan improvisasi yang dibuat sebelumnya. 
Struktur dari penyajian karya tari ini disusun berdasarkan rancangan pada tahap eksplorasi yang kemudian dibakukan menjadi bentuk tarian utuh

\section{HASIL DAN PEMBAHASAN}

Penelitian ini merupakan sebuah hasil dari proses kreatif dari penggarapan tari yang meliputi pembuatan alat musik, penataan iringan tari/musik tari, rias busana, dan properti tari. Pada proses penelitan dalam pembentukan garapan tari ini tentu sangat diperlukan sebuah metode sebagai upaya untuk memudahkan peneliti dalam penyusunannya.

\section{Proses Kreatif Tari Dangiang Wulung}

Pembuatan karya seni dibutuhkan kemampuan kreatifseorang seniman. Seseorang dapat dikatakan kreatif jika memiliki sebuah gagasan atau sebuah pandangan dari keilmuan yang dimilikinya berdasarkan hasil pemikiran berdayacipta. Hasil pemikiran tersebut tentu saja mengalami beberapa proses ide, eksplorasi ruang dan gerak, sampai kepada hasil yang diinginkannya. Munandar mengartikan sebuah kreatifitas bahwa,

"Kreatifitas adalah hasil interaksi antarindividu dan lingkungannya, kemampuan untuk membuat kombinasi baru, berdasarkan data, informasi, atau unsur-unsur yang sudah ada atau dikenal sebelumnya, yaitu semua pengalaman dan pengetahuan yang telah diperoleh seseorang selama hidupnya baik itu dilingkungan sekolah, keluarga, maupun lingkungan masyarakat". (Munandar, 2004, hlm. 12)

Pernyataan tersebut selaras dengan ide kreatif terhadap latar belakang penelitian ini yang menciptakan tarian dari hasil interaksi lingkungannya. Sehingga tercipta sebuah Tari Dangiang Wulung ini yang memiliki identitas bagi lingkungan masyarakat Selaawi.

Pada proses pembentukan karya tari Dangiang Wulung ini semua unsur yang melengkapi penciptaannya dilakukan berdasarkan teori menurut Alma M. Hawkins bahwa "proses kreatif terdiri atas lima tahapan yakni sensing, feeling, imaging, transforming, dan forming". (2003, hlm. 15-16)

Pada tahapsensing yang berartimerasakan, merasakan hal-hal dapat dibentuk untuk dijadikan sebuah bentuk seni yang baru. Feeling yang berarti penghayatan atau menghayati, proses bagaimana mengamati apa yang ada di masyarakat untuk dapat dijadikan sebuah ide gagasan pada bentuk-bentuk penciptaan yang dihasilkan pada tarian ini. Imaging atau pada hal ini diartikan sebagai imajinasi yang dihasilkan dari proses sensing dan feeling. Tahap imajinasi ini bentuk pengejawantahan pikiran yang nantinya mampu mengungkapkan sebuah ide terhadap gambaran penciptaan karya tari ini. Transforming, pada tahapan ini merupakan proses pembentukan dari imajinasi menjadi sebuah gerak, bentuk alat dan bentuk irama. Pada tahap terakhir yaitu Forming, yang merupakan pembentukan secara keseluruhan dari gerak, alat musik dan irama yang mampu memberikan harmonisasi pada struktur Tari Dangiang Wulung.

\section{Hasil Garap Tari}

Tari Dangiang Wulung mengambil genre tari rakyat. Genre tersebut dibuat agar masyarakat nantinya bisa dengan mudah 
mempelajari gerakan tarinya. Gerak yang terdapat pada tarian ini mengambil pada pola kehidupan masyarakat serta kesenian yang telah berkembang di sana.

Sinopsis tarian ini menceritakan tentang kehidupan masyarakat Selaawi yang memanfaatkan awi (bambu) sebagai sumber kehidupannya. Latar belakang cerita dari tarian ini menceritakan sekelompok orang yang sedang melakukan aktivitas keseharian seperti menampi beras, memanen hasil kebun, membuat kerajinan bambu, menanak nasi, dan kegiatan keseharian lainnya. Hasil dari kegiatan keseharian mereka menghasilkan nilai yang membuat perekonomian masyarakat menjadi lebih baik. Pada akhirnya masyarakat mampu menghidupi kebutuhan dengan kemampuan dan usaha mereka dalam sumber daya alam yang ada, terutama bambu. Karakter tarian ini lincah yang menggambarkan kebahagiaan masyarakat dalam mengolah sumber daya alam yang baik untuk kehidupan dan perekonomian mereka.

\section{Struktur Koreografi}

Pada pembentukan koreografi Tari Dangiang Wulung ini menciptakan sebuah tari rakyat sederhana yang memadukan unsur tradisi masyarakat dengan gerak popular di masyarakat. Hal ini dilakukan agar masyarakat nantinya dapat menirukan gerak tersebut dan dengan mudah mempelajarinya tanpa diajarkan oleh orang yang professional.

Penjelasan koreografi menurut Rusliana, “Koreografi diartikan untuk menunjukan gerak yang tersusun dan telah membentuk repertoar tari". (Rusliana, 2016, hlm. 36). Karya tari Dangiang Wulung ini dibagi menjadi 3 struktur

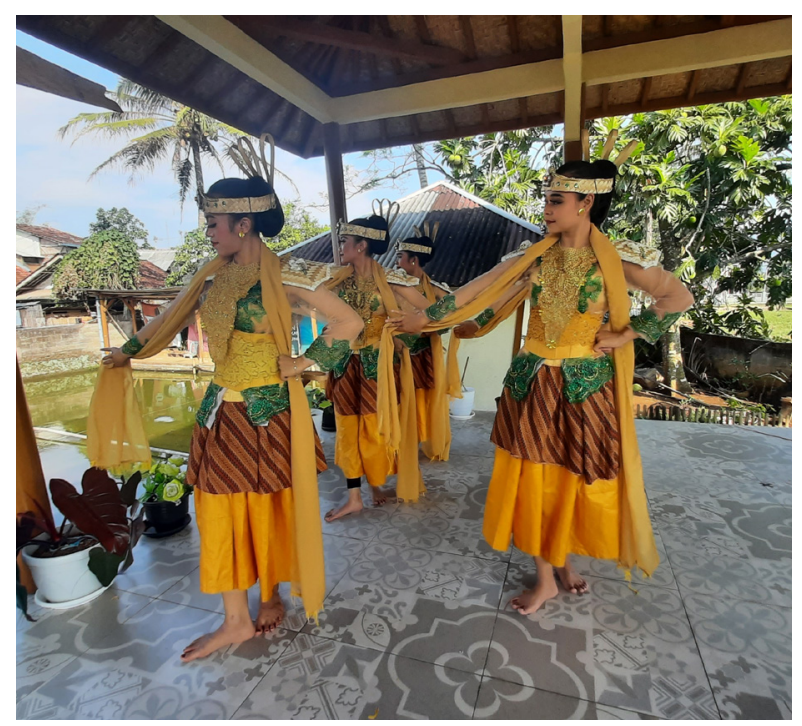

Gambar 1. Penari Menarikan Bagian Awal Tarian (Sumber: Meiga, 2021)

bagian, di antaranya:

Bagian awal mengaktualisasikan fenomena dalam representasi habitus masyarakat Selaawi, di mana para penari sedang melakukan kegiatan keseharian dengan mengolah properti bambu seperti, hihid, boboko, pépéték, nyiru, ayakan dan kerajinan dari bambu lainnya. Pada bagian ini penari mengeksplor gerak dari propertinya masingmasing sehingga memunculkan gerak yang berbeda yang menggambarkan identitas tiap masyarakat yang memiliki perbedaan karakter. Selain itu juga, pada struktur gerak bagian awal ini juga dikaitkan dengan rasa syukur terhadap pencipta yang telah memberikan kelimpahan alam. Hal ini disimbolkan pada bentuk-bentuk gerak yang dilakukan oleh penari dengan menggunakan simbol pola lantai melingkar dan pola-pola gerak tangan keatas sebagai bentuk persembahan. Bentuk tari bagian pertama dapat dilihat pada gambar 1.

Bagian kedua menggambarkan kebanggaan terhadap daerahnya yang memiliki ciri budaya tersendiri. Hal ini diaktualisasikan dengan penggambaran gerak pencak silat yang 


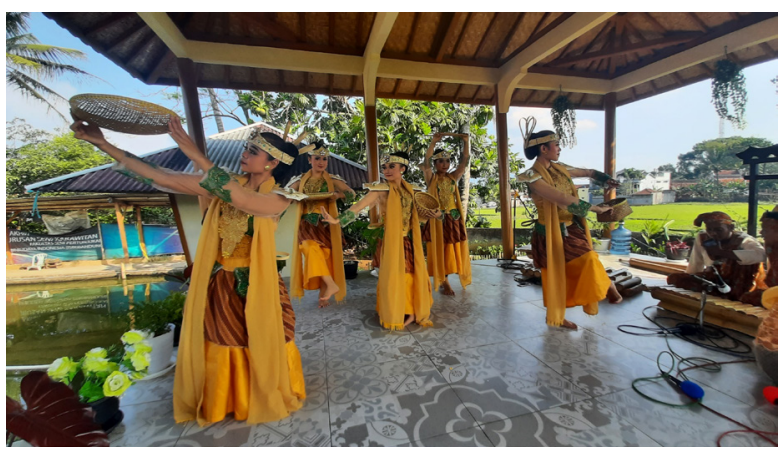

Gambar 2. Penari Menarikan Bagian Kedua (Sumber: Meiga, 2021)

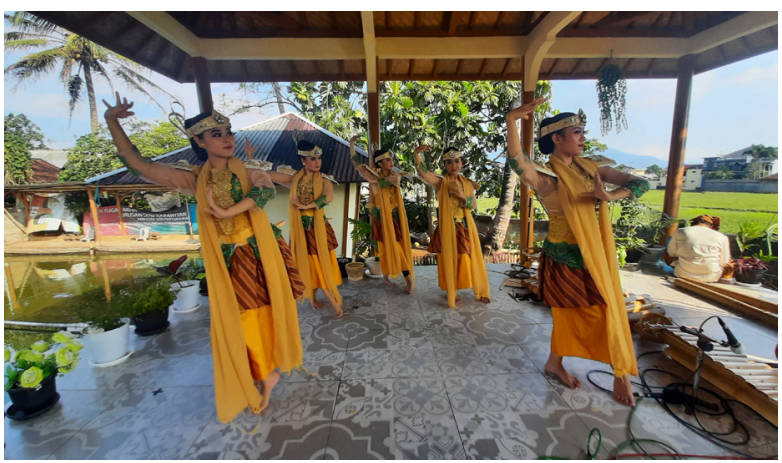

Gambar 3. Penari Menarikan Bagian Ketiga (Sumber: Meiga, 2021)

memiliki karakter maskulin. Karakter tersebut dimunculkan menggambarkan kekuatan yang dimiliki oleh masyarakat Selaawi yang mampu mempertahankan ciri dari daerahnya. Selain itu juga, dapat menggambarkan kekuatan dari masyarakat yang mampu bertahan menghidupi kebutuhan kesehariannya dengan memanfaatkan sumber daya alam disekitarnya. Pada bagianini juga dilihat pada pola gerak yang lebih atraktif dan dinamis ditambah dengan simbol pola membentuk garis-garis lurus yang tegas untuk dapat mengaktualisasikan ketegasan pada geraknya. Bentuk gerak bagian kedua dapat dilihat pada gambar 2 .

Bagian ketiga menggambarkan rasa syukur dengan mengungkapkan kegembiraan karena telah dianugerahi hasil alam yang dapat dimanfaatkan oleh masyarakat. Penggambaran geraknya berupa gerak tradisi rakyat yang menggambarkan kegembiraan. Pola gerak yang digunakan pada adegan akhir ini lebih dinamis, menggunakan pola gerak tangan dan kaki juga menerapkan pola gerak ciri dari tari rakyat seperti gitek, geol, dan goyang. Penambahan gerak-gerak tersebut dilakukan sebagai simbol kesuburan. Bentuk gerak pada bagian akhir bisa dilihat pada gambar 3 .

\section{Proses Kreatif Musik Tari Dangiang Wulung}

Sebuah penciptaan tari tentunya sangat erat dengan iringan tari atau musik tarinya. Hal tersebut berkaitan karena musik merupakan salah satu unsur penunjang dalam tari. Selain itu juga, musik dalam tari dapat menambah suasana yang disampaikan dalam gerak juga sebagai pengantar pesan yang ingin disampaikan oleh seorang koreografer terhadap gerak melalui irama atau iringan musik tarinya.

“Setiap karya seni musik tentunya mengandung pesan yang ingin disampaikan kepada penghayat. Pesan itu berupa nilai-nilai luhur dan mulia yang sangat berguna bagi perkembangan jiwa manusia".

(Wiflihani, 2016, hlm. 102)

Musik dalam tari merupakan hal yang sangatberkaitandantidakdapatdipisahkan.Hal tersebut sudah tentu karena tari menggunakan musik sebagai pemberi pesan atau perantara komunikasi sebagai isyarat pencipta suasana maupun nilai filosofis di dalamnya. Seperti dikatakan Royce bahwa, "Tari mengirimkan tanda-tanda yang dimilikinya juga dengan perkakas bunyi"(2007, hlm. 216).

Pengolahan iringan atau musik pada garapan karya tari Dangiang Wulung ini menggunakan alat musik yang berbahan dasar bambu. Seperti yang telah dijelaskan sebelumnya bahwa karya tari ini mengangkat 
ciri dari daerah Selaawi yang memiliki ciri dari unsur sumber daya alam bambu. Penggunaan bambu pada karya tari ini juga berlaku dengan alat musiknya agar pengolahan bambu tersebut bisa dimanfaatkan juga oleh masyarakat sebagai bentuk alat musik yang bisa dikembangkan.

Adapun proses kreatif yang dilakukan, antara lain:

1. Ekplorasi Bentuk

Melalui penelaahan dari berbagai referensi, dapat disimpulkan bahwa di samping dari jenis bambu yang biasa digunakan sebagai bahan instrumen musik, juga sumber nada yang dapat dihasilkan dari media bambu, antara lain dari bagian tabung/ruas bambu, dari bentuk bilahan, dan penggabungan di antara keduanya.

Melalui penelaahan dari berbagai referensi, peneliti menyimpulkan bahwa di samping dari jenis bambu yang biasa digunakan sebagai bahan instrumen musik, juga sumber nada yang dapat dihasilkan dari media bambu, antara lain dari bagian tabung/ruas bambu, dari bentuk bilahan, dan penggabungan di antara keduanya.

Namun demikian, dalam hal eksplorasi ini peneliti mencoba menghadirkan bentuk instrumen yang berbeda dari yang sudah ada sebelumnya, seperti angklung, calung, arumba, dll. Oleh karena itu, dalam tahap eksplorasi ini mencoba membuat bentukan instrumen "baru" dengan tetap berpijak pada sumber penciptaan yang sudah ada.

Dari bentuk tabung, dengan mengambil inspirasi dari kohkol atum, dapat dihasilkan suatu instrumen dengan bentuk seperti terlihat pada gambar 4 .

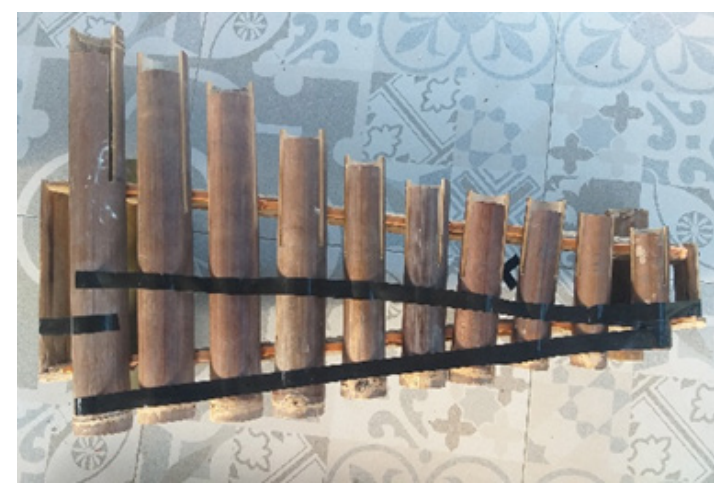

Gambar 4. Alat Musik Kotum (Sumber: Meiga, 2021)

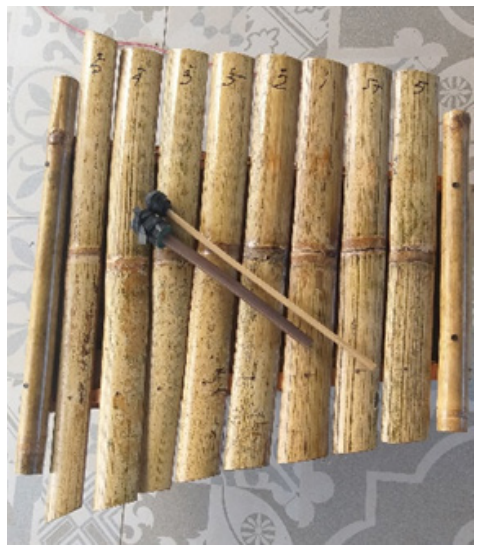

Gambar 5. Alat Musik Marque (Sumber: Meiga, 2021)

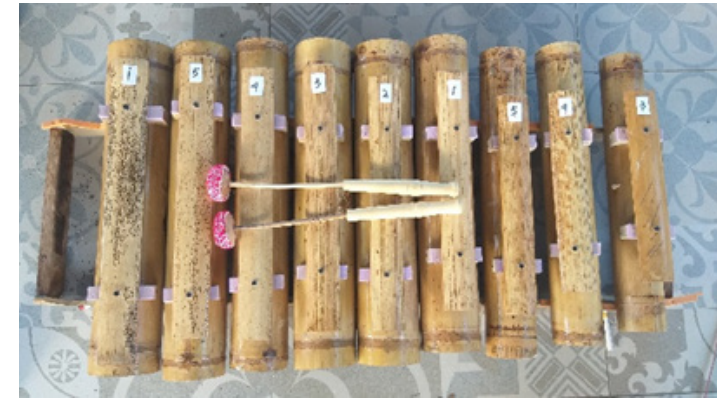

Gambar 6. Alat Musik Sarwi (Sumber: Meiga, 2021)

Adapun dari bentuk bilahan, dapat dihasilkan suatu instrumen seperti gambar 5 .

Sementara itu, proses eksplorasi yang membutuhkan waktu cukup lama, yaitu membuat instrumen yang menggabungkan antara tabung dan bilah. Hal itu disebabkan oleh penyesuaian antara ukuran tabung dan bilah yang harus tepat, sehingga bisa menghasilkan bunyi dan karakter bunyi yang diinginkan. Adapun bentuk instrumen gabungan tabung dan bilah, seperti gambar 6 . 


\section{Eksplorasi Nada}

Setelah proses ekplorasi bentuk instrumen dihasilkan, maka tahapan berikutnya yang jauh lebih rumit adalah proses pembentukan nada pada tiap tabung/bilah tersebut. Setelah melalui proses eksplorasi yang cukup panjang dan rumit, maka dapat dihasilkan bunyi nada sesuai dengan yang diharapkan. Dalam pembuatan instrumen untuk musik/karawitan tari Dangiang Wulung kali ini, ditetapkan untuk menggunakan laras Degung.

Ketiga instrumen "baru" ini dalam penggarapan musikalnya ditambahkan pula instrumen konvensional (kendang dan goong), serta dilengkapi beberapa perkusi tak bernada (atonal) yang juga terbuat dari bahan bambu. Perangkat tersebut kami namakan "Wiragawi" (Wiraga Awi/bentuk fisiknya bambu).

\section{Eksplorasi Musikal}

Pada penggarapan iringan tari menyesuaikan dengan struktur pada tariannya sendiri. Pada bagian awal musik hanya mengiringi dengan irama ketukan mengikuti gerakan penari. Pada bagian kedua iringan menggunakan nada dan karakter yang kuat agar penggambaran suasana dengan gerak tari selaras. Pada bagian ketiga penggambaran musik dengan irama cepat dan bernada atau menggunakan lagu agar terlihat lincah dan menggambarkan kegembiraan.

\section{Penataan Artistik Tari}

Penataan artistik pada tari mencakup berbagai macam seperti tata pentas, setting, lighting, rias, busana, dan propertinya. Pada halnya yang dilibatkan pada penciptaan karya Tari Dangiang Wulung ini, penataan artistik yang ditonjolkan hanya pada rias, busana, dan properti tarinya saja. Kegunaan artistik tersebut tentunya memiliki nilai yang menyangkut ke dalam unsur-unsur identitas yang menjadi ciri atau gaya di Selaawi. Selain itu juga dijelaskan bahwa,

“Di samping hal tersebut busana dan rias merupakan elemen struktur Pandhelori yang tidak boleh diabaikan karena di dalamnya sejumlah nilai, sejumlah pesan artistik itu dikapsulkan lewat warna, model busana, bentuk dan macam accesories, jenis riasannya dan sebagainya". (Nuryani, 2020, hlm.310)

Terkait pada penataan artistik tari yang menyangkut pada penciptaan Tari Dangiang Wulung ini, maka dapat dilihat berdasarkan nilai yang terkandung dalam penataan rias, busana, dan properti tari.

1. Rias dan Busana

Peran rias dan busana dalam pertunjukan tari merupakan sesuatu yang sangat penting sebagai penunjang estetika di atas panggung. Selain itu juga, rias dan busana dapat menonjolkan ciri atau karakter dari tariannya sendiri.

Pemunculkan karakter dalam karya tari Dangiang Wulung ini dapat dilihat dari bentuk rias dan busana yang digunakan. Seperti pada rias, hanya menggunakan rias sederhana atau rias cantik. Penggunaan rias minimalis menjadikan sebuah ciri kesederhanaan dari bentuk tarian rakyat. Selain itu juga, pada tarian ini tidak membutuhkan riasan wajah karakter dan menampilkan wajah sebagai ciri sederhana seorang wanita desa. Bentuk riasan dapat dilihat pada gambar 7 .

Sedangkan untuk memunculkan ciri dari bentuk karya nya sendiri dapat dilihat dari busana atau kostum. Pada busana atau kostum 


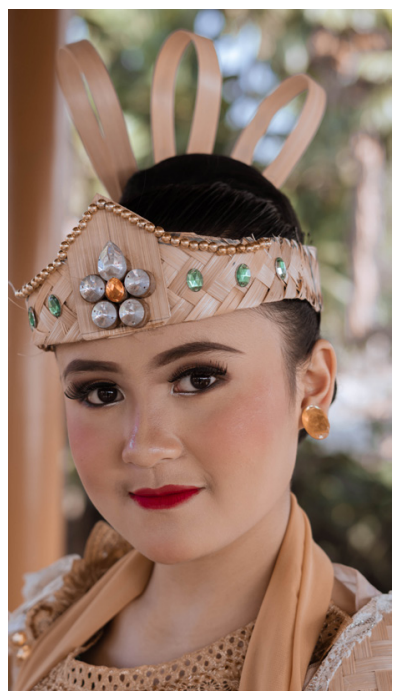

Gambar 7. Rias Wajah Tari Dangiang Wulung (Sumber: Meiga 2021)

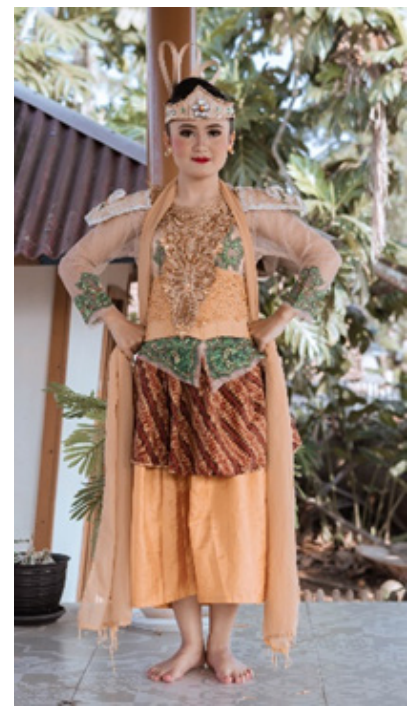

Gambar 8. Kostum Tari Dangiang Wulung (Sumber: Koleksi Restu, 2021)

yang dipakai oleh penari menggunakan unsur bambu yang menjadi ciri dari tariannya. Seperti pada pemakaian aksesoris kepala (makuta dan anting), pada bagian pinggang, serta bagian bahu.

Penggunaan bambu dalam busana tari Dangiang Wulung ini tentunya dibuat senyaman mungkin pada saat dipakai oleh penari, sehingga penari masih dapat dengan leluasa bergerak. Penggunaan bambu ini dimaksudkan untuk menjadi daya tarik dan juga ciri khas dari tariannya. Bentuk busana tari dapat dilihat pada gambar 8 .

\section{Properti}

Penggunaan properti pada karya tari Dangiang Wulung ini masih berpatokan pada unsur bambu. Properti dalam tari ini memiliki 2 penggunaan, yang pertama properti yang digunakan secara terpisah atau Handprop dan properti yang digunakan menempel dengan busana atau kostum tarinya. "Properti bisa berupa alat tersendiri, bisa pula bagian dari tata busana". (Sumaryono dan Endo, 2006, hlm. 104) Pada Handprop yang digunakan adalah Hihid, Boboko, Nyiru, Pépéték dan dingkul. Sedangkan properti yang digunakan menempel dalam busana yaitu menggunakan sampur atau sodér. Properti yang digunakan tersebut tentu akan menambah ciri khas pada tarian ini karena menggunakan bambu sebagai bahannya.

\section{SIMPULAN}

Karya Tari Dangiang Wulung merupakan tarian yang dibentuk berdasarkan ciri dan identitas dari yang berada di Kecamatan Selaawi. Bentuk tarian ini adalah tari rakyat yang menggambarkan kebahagiaan masyarakat dalam mengolah sumber daya alam yang baik untuk kehidupan dan perekonomian mereka. Penambahan unsur bambu pada garapan ini mencoba untuk membuat karya tari yang memiliki ciri khas daerahnya. Sehingga karya tari Dangiang Wulung ini menonjolkan identitas Selaawi sebagai daerah penghasil bambu. Maka dari itu, pada penciptaan tarian ini membawakan unsur bambu dari mulai pembuatan alat musik, busana, dan properti tarinya.

Penciptaan Tari Dangiang Wulung merupakan hasil dari penelitian berdasarkan 
pencarian identitas pada masyarakat Selaawi.

Kurangnya sumber daya manusia pada wilayah Selaawi menjadikan kurangnya pemanfaatan sumber daya alam sebagai potensi untuk mengembangkan seni dan budaya di wilayah tersebut. Pada hal ini identitas budaya sebagai ciri suatu daerah menjadi penting adanya.

Bambu yang menjadi pembentuk dari peran masyarakat terhadap perekonomian dan kehidupannya. Terlebih lagi masyarakat Selaawi yang memanfaatkan bambu sebagai mata pencahariannya. Hal tersebut menunjukan bahwa kehidupan masyarakat Selaawi yang berpegang pada bambu sebagai penyambung kehidupannya. Dalam hal ini masyarakat Selaawi telah mampu memanfaatkan bambu dengan segala pengolahannya. Sehingga dalam hal ini Selaawi dikenal dengan pengolahan bambu sebagai identitas wilayahnya.

Adanya proses penciptaan tarian ini menjadikan sebuah revitalisasi seni budaya sebagai inspirasi kepada masyarakat lainnya untuk bisa memberikan kontribusi yang sama terhadap kehidupan seni budaya agar lebih tumbuh dan berkembang.

\section{UCAPAN TERIMAKASIH}

Terimakasih kepada Institut Seni Budaya Indonesia (ISBI) Bandung yang telah memberikan dana hibah DIPA pada penelitian ini.

\section{DAFTAR PUSTAKA}

Brandon, James R. (2003). Jejak-jejak Seni Pertunjukan di Asia Tenggara. Bandung: P4ST UPI.

Denzin, Norman K. Dan Lincoln Yvona S. (2009). Hand Book Of Qualitative Research. Diterjemahkan oleh Dariyatno dkk. Yogyakarta: Pustaka Pelajar.

Hadi, Y. Sumandiyo. (2003). Aspek-aspek Dasar koreografi kelompok. Yogyakarta: Lembaga Kajian Pendidikan dan Humaniora Indonesia.

Hawkins, Alma, M. (1991). Moving from Within: a New Method for Dance Making. Diterjemakan oleh Dibia, I Wayan. (2003). Bergerak Menurut Hati. Jakarta: Ford Fondation dan MSPL.

Munandar, Utami. (2004). Pengembangan Emosi dan Kreativitas. Jakarta: Rineka Cipta.

Nalan, Arthur S. (2008). Seni Pertunjukan untuk Semua Orang: Konsep Perlakuan dan Pewarisan. dalam Tradisi sebagai Tumpuan Kreativitas Seni. Bandung: Sunan Ambu Press.

Nuryani, Wenti. (2020). Nilai-Nilai Pendidikan Tata Busana dan Rias Srimpi Pandhelori dalam Perspektif Hermeneutik. Panggung 30 (2), 307-324

R.M. Soedarsono. (1997). Wayang Wong: Drama Tari Ritual Kenegaraan di Keraton Yogyakarta. Yogyakarta: Gadjah Mada University Press.

Rusliana, Iyus. (2016). Tari Wayang. Bandung: Jurusan Tari ISBI.

Royce, Anya Peterson. (1980). The Antropology of Dancei. Diterjemahkan oleh F.X. Widaryanto. (2007). Bandung: Sunan Ambu Press.

Saini, KM. (2008). Sekolah Tinggi Seni Indonesia Bandung dan Infrastruktur Kesenian di Jawa Barat, dalam Tradisi sebagai Tumpuan Kreativitas Seni. Bandung: Sunan Ambu Press.

Sumaryono dan Endo Suanda. (2006). Tari Tontonan. Jakarta: Lembaga Pendidikan.

Stuart Hall (Ahli Teori Kebudayaan). Diakses pada 24 April 2021 dari https:// id.m.wikipedia.org/wiki/Stuart_Hall_ (ahli_teori_kebudayaan)

Wahyuni, Wahida dan Yusfi 1, Suharti. (2018). 
Karakteristik Gaya Tari Minangkabau Tari Mulo Pado dan Tari Benten. Panggung 28 (2), 246.

Widnyana, (2021), Bambu Dengan Berbagai Manfaatnya. Diakses pada 13 Oktober 2021 dari https://www.academia.edu/ download/49027809/2418-3144-1-SM. pdf

Wiflihani, (2016), Fungsi Seni Musik dalam Kehidupan Manusia, Anthropos: Jurnal Antropologi Sosial dan Budaya, 2 (1), 10110 